\title{
Storage iron depletion in male blood donors: its significance for iron status in women
}

\author{
J. FIELDING, C. KARABUS, AND GILLIAN M. BRUNSTRÖM \\ From St Mary's Hospital, Harrow Road, London
}

SYNOPSIS Among 24 male blood donors without anaemia who had been giving a mean of $2 \cdot 22^{\circ}$ donations per year involving a mean blood loss of about $900 \mathrm{ml}$ a year, $10(41 \%)$ were found to be depleted of storage iron. This is somewhat higher but similar to the previously recorded findingsin in healthy women without anaemia.

The results may well support a policy of limiting blood donation to twice a year in men and to once a year in women. Both men and women blood donors require medicinal iron after each ${ }^{N}$ donation.

It is considered that storage iron depletion in non-anaemic women is not in the main related to pathological levels of menstrual loss but rather to inadequate dietary iron. Food iron in present-day@ diets should be supplemented.

In a previous study (Fielding, O'Shaughnessy, and Brunström, 196.5) it was shown that there was less storage iron, measured as desferrioxamine chelatable iron, in healthy women than in healthy men. In as many as a third of normal women without anaemia, i.e. with haemoglobin concentration above $12.0 \mathrm{~g}$ per $100 \mathrm{ml}$, storage iron was in the same range as in severe iron-deficiency anaemia, in which it is known with certainty that storage iron is depleted. As in the well known mild chronic anaemia which afflicts numerous women, the most likely explanation of this finding is the effect of menstrual loss on iron status. It has been shown by direct measurement (Frenchman and Johnson, 1949; Hallberg, Högdahl, Nilsson, and Rybo, 1966) that about $20 \%$ of women lose more than $60 \mathrm{ml}$ menstrual blood per cycle; in some cases the loss exceeds $400 \mathrm{ml}$ per cycle. Many such women seem unaware that their losses are unusual.

The nett effect of menstrual loss on haematological status depends not only on the amount lost but on dietary iron intake and the efficiency of intestinal absorption. It is uncertain therefore whether storage iron depletion in a high proportion of women is related to menstrual loss which could reasonably be considered pathological, or whether their iron deficiency is related to dietary and intestinal factors.

In order to assess the effect of intermittent blood loss of known amount on storage iron status,

Received for publication 5 October 1967. desferrioxamine chelatable iron was measured in male blood donors and the results are reported here.

\section{METHODS}

Desferrioxamine chelatable iron was measured by the differential ferrioxamine test (Fielding, 1965). The procedure consists of an intravenous injection of a bodyweight dose of desferrioxamine methanesulphonate (Desferal, Ciba) together with a body-weight dose of 8 ferrioxamine labelled with $2 \mu \mathrm{C}^{59} \mathrm{Fe}$. A six-hour specimen 흠 of urine is collected. The amount of injected ferrioxamine excreted is estimated as ${ }^{59} \mathrm{Fe}$ by standard methods and $\dot{\delta}$ the total amount of ferrioxamine excreted is estimated chemically. The difference between the two estimations 0 gives the amount of ferrioxamine which has been derived from chelation of storage iron in vivo; the amount of $\frac{D}{O}$ ferrioxamine formed from body iron (Fv) is calculated by simple proportion and expressed in micrograms $N$ ferrioxamine hydrochloride per kilogram body weight.

Serum iron was determined by the method of Kok and $N$ Wild (1960) and total serum iron-binding capacity 代 (TIBC) by the adsorption of excess ferric chloride with magnesium carbonate (Ramsay, 1957).

Unless otherwise stated, mean values are quoted with their standard errors. Mean values are referred to as 'significantly' different when they differ by more than ? twice the standard error.

\section{CLINICAL SUBJECTS}

BLOOD DONORS Twenty-four men volunteered for the tests as the result of an appeal by the British Red Cross 
Society. Their history varied from five to 92 donations given over two to 30 years; in the group as a whole a mean of 33 blood donations had been given in $15 \cdot 3$ years, that is $\mathbf{2 \cdot 2}$ donations per year (Table I). The wide range of blood donor history was specially suitable for the purpose of the investigation since it corresponded to varying times elapsed since the menarche in the healthy women previously reported. No blood had been donated during the four weeks before the test.

\section{TABLE I}

DONATION HISTORY AND STORAGE IRON STATUS

\begin{tabular}{|c|c|c|c|c|c|}
\hline $\begin{array}{l}\text { Storage Iron } \\
\text { Status }\end{array}$ & No. & $\begin{array}{l}\text { Total Units } \\
\text { Mean Given } \\
\text { (range) }\end{array}$ & $\begin{array}{l}\text { Mean Time } \\
\text { as Donors } \\
\text { Years } \\
\text { (range) }\end{array}$ & $\begin{array}{l}\text { Donations } \\
\text { per Year } \\
\text { Mean } \pm \\
S D\end{array}$ & $\begin{array}{l}F v(\mu g / k g) \\
M e a n \pm \\
S D\end{array}$ \\
\hline $\begin{array}{l}\text { Depleted } \\
(\mathrm{Fv}<110 \\
\mu \mathrm{g} / \mathbf{k g})\end{array}$ & 10 & $\begin{array}{l}36 \\
(5-79)\end{array}$ & $\begin{array}{l}15.9 \\
(2-30)\end{array}$ & $2.3 \pm 0.6$ & $44 \pm 34$ \\
\hline $\begin{array}{l}\text { Normal } \\
(\mathrm{Fv} \geqslant 110 \\
\mu \mathbf{g} / \mathbf{k g})\end{array}$ & 14 & $\begin{array}{l}30 \\
(5-92)\end{array}$ & $\begin{array}{l}14 \cdot 8 \\
(3-30)\end{array}$ & $2.0 \pm 0.7$ & $190 \pm 83$ \\
\hline Combined & 24 & 33 & $15 \cdot 3$ & $2 \cdot 2 \pm 0.7$ & $129 \pm 99$ \\
\hline
\end{tabular}

SD $=$ standard deviation

The results in these blood donors are compared with those in 31 healthy men, in 37 patients with unequivocal iron-deficiency anaemia, and in 45 apparently healthy women previously described (Fielding, O'Shaughnessy, and Brunström, 1965).

\section{RESULTS}

FV VALUES The distribution of Fv values (ferrioxamine formed from body iron by the standard intravenous dose of desferrioxamine) in the four groups is shown in the figure. The mean Fv values of the 24 blood donors was $129 \pm 20 \mu \mathrm{g} / \mathrm{kg}$ compared with $238 \pm 19 \mu \mathrm{g} / \mathrm{kg}$ in 31 healthy men and $146 \pm 17 \mu \mathrm{g} / \mathrm{kg}$ in 45 healthy women.

Of the 24 male blood donors, 10 (41\%) gave Fv values below $110 \mu \mathrm{g} / \mathrm{kg}$, that is, below the range in healthy men and in the range of patients with severe iron-deficiency anaemia. These 10 subjects are therefore considered to be depleted of storage iron. Four of these would have been suspected of sideropenia from their low serum iron values and high total iron-binding capacity. In the previously investigated groups, healthy men gave no Fv values below $110 \mu \mathrm{g} / \mathrm{kg}$, while $33 \%$ of apparently healthy women were below this value (Table II).

\section{TABLE II}

STORAGE IRON STATUS

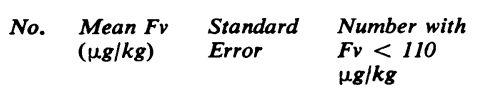

\begin{tabular}{lllll}
\hline Healthy males & 31 & 238 & $\pm 19 \cdot 4$ & 0 \\
Healthy females & 45 & 146 & \pm 16.5 & $15(33 \%)$ \\
Blood donors & 24 & 129 & $\pm 20 \cdot 2$ & $10(41 \%)$
\end{tabular}

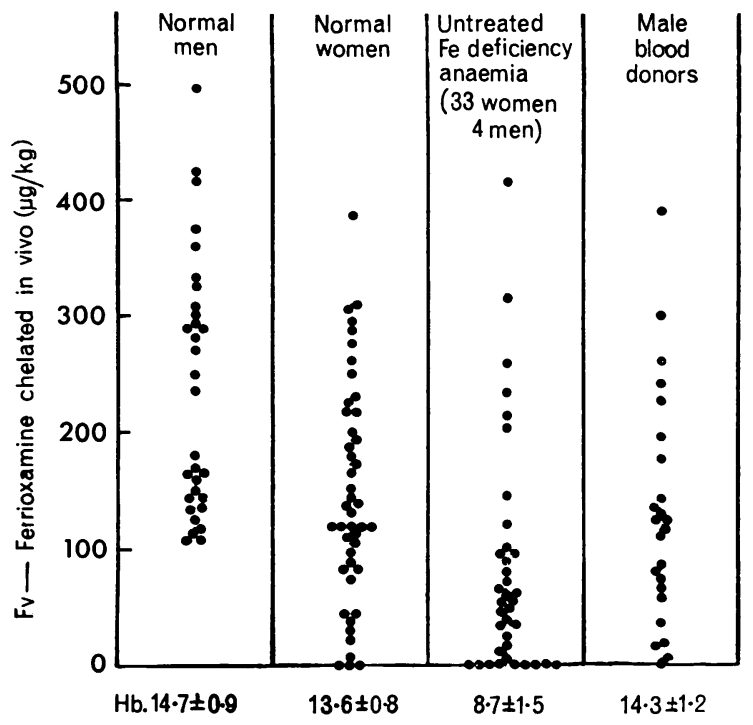

Scattergram of $\mathrm{Fv}$ values in four groups. $\mathrm{Hb}=$ Haemoglobin concentration in $\mathrm{g}$ per $100 \mathrm{ml} \pm$ standard deviation.

HAEMOGLOBIN AND FV The mean haemoglobin concentration of the healthy men and the blood donors did not differ significantly, $14.7 \pm 0.2 \mathrm{~g}$ per $100 \mathrm{ml}$ and $14.3 \pm 0.2 \mathrm{~g}$ per $100 \mathrm{ml}$ respectively.

SERUM IRON AND FV The mean serum iron concentration of the male blood donors, $102 \pm 7 \mu \mathrm{g}$ per $100 \mathrm{ml}$, was significantly lower than for non-donor men (116 \pm 4$)$ and resembled that of the normal women (102 \pm 5$)$. There were no differences between serum iron concentrations in blood donors with storage iron depletion and those with normal storage iron.

TIBC AND FV The total iron-binding capacity of the blood donors was greater than that of both healthy men and women. The mean TIBC was particularly raised in the blood donors with storage iron depletion, $409 \pm 25 \mu \mathrm{g}$ per $100 \mathrm{ml}$, when compared with both normal men and blood donors with normal storage iron. This finding agrees with those of Weinfeld (1964), who showed that the first effect of storage iron depletion is seen in the peripheral blood as an increase of TIBC: it also adds to the evidence that mean Fv values are a sensitive measure of storage iron status. However, the range in the various groups overlap considerably and TIBC cannot be used to assess storage iron status in a given subject. The haematological data are summarized in Table III. 


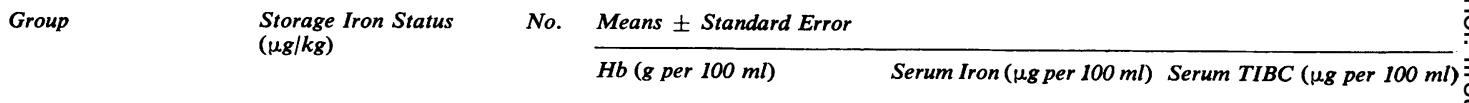

\begin{tabular}{llrr}
\hline Normal males & Fv 110-500 & 31 & $14.7 \pm 0.2$ \\
Normal females & Fv < 110 & 15 & $13.4 \pm 0.2$ \\
& Fv 110 or more & 30 & $13.7 \pm 0 \cdot 2$ \\
& Combined & 45 & $13.6 \pm 0.1$ \\
Untreated iron- & Fv < 110 & 29 & $8 \cdot 7 \pm 0.3$ \\
deficiency anaemia & Fv 110 or more & 8 & $8 \cdot 7 \pm 0.6$ \\
& Combined & 37 & $8.7 \pm 0.2$ \\
Male & Fv < 110 & 10 & $14.7 \pm 0.2$ \\
blood donors & Fv 110 or more & 14 & $14.1 \pm 0.4$ \\
& Combined & 24 & $14.3 \pm 0.2$
\end{tabular}

$\begin{array}{ll}116 \pm 4 & 331 \pm 11 \\ 100 \pm 9 & 381 \pm 18 \\ 103 \pm 6 & 348 \pm 12 \\ 102 \pm 5 & 359 \pm 10 \\ 28 \pm 4(28)^{1} & 437 \pm 20(28) \\ 19 \pm 4 & 428 \pm 29 \\ 26 \pm 4(36) & 435 \pm 17(36) \\ 100 \pm 10 & 409 \pm 25 \\ 103 \pm 10 & 345 \pm 15 \\ 102 \pm 7 & 372 \pm 15\end{array}$

${ }^{1}$ Figures in parentheses indicate number in group when different from main group.

\section{DISCUSSION}

Several previous investigations have demonstrated the diminished iron status often found among regular blood donors (Weinfeld, 1964; Mollison, 1967). The present results show that in 10 out of 24 male donors without anaemia, storage iron was depleted to the same extent as found in patients with severe iron-deficiency anaemia. Although these donors had no anaemia, in some instances a low serum iron level was found and more frequently a high serum iron-binding capacity.

The donors who suffered storage iron depletion had given blood for a mean of 15.9 years with a mean of 2.3 donations a year. Those with storage iron in the normal range had as a group been donors for a somewhat shorter period, with a mean of 14.8 years, and had donated blood slightly less frequently with a mean of 2.0 donations a year. The differences in frequency are not large but they amount to a mean difference of about $1,000 \mathrm{mg}$ iron loss between the two groups during their donor experience. A detailed dietary history revealed no differences in dietary iron in the two groups. It remains possible that the smaller group of donors with depleted storage iron are those whose capacity to augment intestinal iron absorbed from iron in food after blood loss is not as great as in the larger group.

These figures support a policy of restricting blood donation from men to twice a year, that is to a blood loss of about $900 \mathrm{ml}$. It should be recognized that a corollary of such a policy is to limit blood donation from women to once a year since they already experience a mean physiological loss of about $500 \mathrm{ml}$ per year. It would appear important to offer medicinal iron to both men and women blood donors after each donation; to what extent this would permit more frequent donation is not known.

A mean loss of $2 \cdot 3$ transfusion units of blood in male donors with storage iron depletion is the equivalent of about $960 \mathrm{ml}$ blood loss per year, while a mean loss of $2 \cdot 1$ units among those with normal storage iron is the equivalent of about $880 \mathrm{ml}$ 응 per year. Blood loss in these circumstances is not $\rightarrow$ of course quite comparable with losses in men- 3 struating women, since it is incurred at less frequent intervals, but it is nevertheless arithmetically equiva- $\vec{\varphi}$ lent to menstrual loss of about $80 \mathrm{ml}$ and $70 \mathrm{ml}$ per cycle respectively. Our results have shown that healthy men with blood losses of this order haveo among them about $40 \%$ with depleted storage iron. The proportion of apparently healthy women with-응 out anaemia who were found to be depleted of iron by $\frac{\mathbb{Q}}{\varnothing}$ the same test is $30 \%$ : it is highly probable, therefore, $\varrho$ that these iron-depleted women without anaemia $\overrightarrow{\vec{B}}$ were not as a group experiencing blood losses of 3 more than 70 to $80 \mathrm{ml}$ per cycle. This conclusion supports the observations of Hallberg et al (1966)? who found no change in the mean haemoglobino concentration of women in Göteborg with menstrual:losses of up to $100 \mathrm{ml}$ per cycle, but there was a perceptible trend to low serum iron values and high TIBC when losses rose above $60 \mathrm{ml}$ per cycle.

It is obvious that iron status in women dependso not only on blood loss but on the amount of food iron and intestinal absorption. It may be reasonableo to consider losses of over $100 \mathrm{ml}$ per cycle as pathological, since this appears to be invariably accom- $\sigma$ panied by anaemia. It is, however, equally unreason- $N$ able to consider as pathological smaller losses in N women who complain of no inconvenience and on $\sigma$ investigation show no gynaecological or other pathology. Yet $30 \%$ of such apparently normafe women without anaemia are found to be depleted of storage iron. In this situation a change of em-phasis is needed from the role of menstrual loss to the role of inadequate iron intake.

It seems that the amount of iron which can be absorbed from a modern diet is inadequate to 0 provide normal iron stores for about a third of 
normal women. With the growing evidence that latent iron deficiency has its own symptomatology there would appear to be a widespread need, perhaps in a public health context, to supplement food iron in present-day diets.

We wish to thank the British Red Cross Society and their blood donors for their helpful cooperation.

This study has been supported by grants from the Medical Research Council and the North West Metropolitan Regional Hospital Board.

\section{REFERENCES}

Bothwell, T. H., and Mallett, B. (1955). Biochem. J., 59, 599. Fielding, J. (1965). J. clin. Path., 18, 88. O'Shaughnessy, M. C., and Brunström, G. M. (1965). Lancet, $2,9$.

Frenchman, R., and Johnson, F. A. (1949). J. Amer. diet. Ass., 25, 217. Hallberg, L., Högdahl, A. M., Nilsson, L., and Rybo, G. (1966). Acta med. scand., 180, 639.

Kok, D'A., and Wild, F. (1960). J. clin Path. 13, 241.

Mollison, P. L. (1967). Blood Transfusion in Clinical Medicine, 4th ed. p. 2. Blackwell, Oxford.

Ramsay, W. N. M. (1957). Clin chim. Acta, 2, 221.

Weinfeld, A. (1964). Acta med. scand., suppl. 427, 58. 